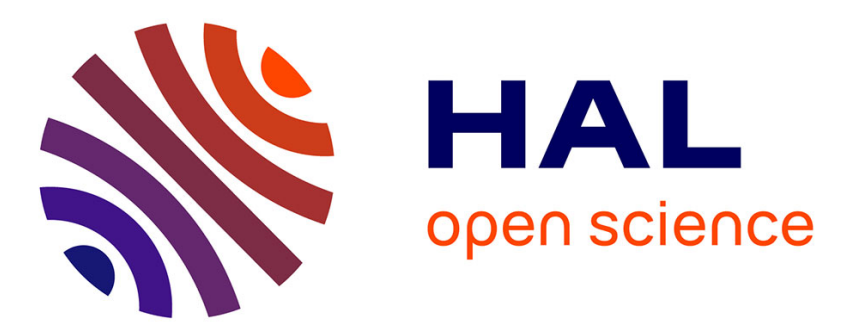

\title{
Use of electrochemical techniques to study the corrosion of metals in model fluoride melts
}

Stéphanie Fabre, Céline Cabet, Laurent Cassayre, Pierre Chamelot, S. Delepech, Jorgen Finne, Laurent Massot, Didier Noël

\section{To cite this version:}

Stéphanie Fabre, Céline Cabet, Laurent Cassayre, Pierre Chamelot, S. Delepech, et al.. Use of electrochemical techniques to study the corrosion of metals in model fluoride melts. Journal of Nuclear Materials, 2013, vol. 441, pp. 583-591. 10.1016/j.jnucmat.2013.03.055 . hal-00877440

\author{
HAL Id: hal-00877440 \\ https://hal.science/hal-00877440
}

Submitted on 28 Oct 2013

HAL is a multi-disciplinary open access archive for the deposit and dissemination of scientific research documents, whether they are published or not. The documents may come from teaching and research institutions in France or abroad, or from public or private research centers.
L'archive ouverte pluridisciplinaire HAL, est destinée au dépôt et à la diffusion de documents scientifiques de niveau recherche, publiés ou non, émanant des établissements d'enseignement et de recherche français ou étrangers, des laboratoires publics ou privés. 


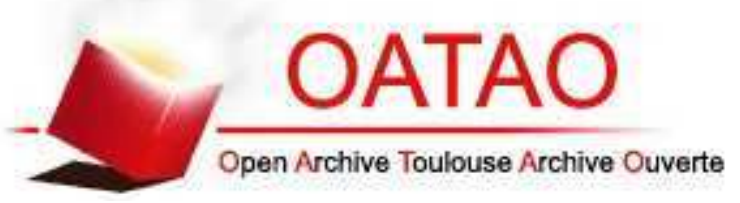

\section{Open Archive TOULOUSE Archive Ouverte (OATAO)}

OATAO is an open access repository that collects the work of Toulouse researchers and makes it freely available over the web where possible.

This is an author-deposited version published in : http://oatao.univ-toulouse.fr/ Eprints ID : 9923

To link to this article : DOI:10.1016/j.jnucmat.2013.03.055

URL : http://dx.doi.org/10.1016/j.jnucmat.2013.03.055

To cite this version : Fabre, Stéphanie and Cabet, Céline and Cassayre, Laurent and Chamelot, Pierre and Delepech, S. and Finne, Jorgenand Massot, Laurent and Noël, Didier. Use of electrochemical techniques to study the corrosion of metals in model fluoride melts. (2013) Journal of Nuclear Materials, vol. 441 ( $\left.{ }^{\circ} 1-3\right)$. pp. 583-591. ISSN 0022-3115

Any correspondance concerning this service should be sent to the repository administrator: staff-oatao@ listes-diff.inp-toulouse.fr 


\title{
Use of electrochemical techniques to study the corrosion of metals in model fluoride melts
}

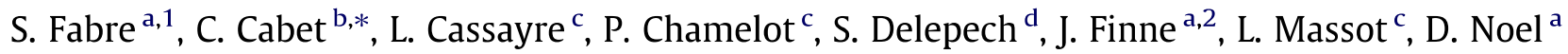 \\ ${ }^{a}$ EDF RED, Département MMC, Groupe Chimie et Corrosion, 77818 Moret-sur-Loing Cedex, France \\ ${ }^{\mathrm{b}}$ CEA, DEN, DPC, SCCME, Laboratoire d'Etude de la Corrosion Non Aqueuse, F-91191 Gif-sur-Yvette, France \\ ${ }^{\mathrm{c}}$ Université Toulouse, INPT, UPS, Laboratoire de Génie Chimique, Département Procédés Electrochimiques, F-31062 Toulouse Cedex 09, France \\ ' ENSCP, Laboratoire d'Électrochimie, de Chimie des Interface et Modélisation pour l'Energie, UMR 7575, 11 rue Pierre et Marie Curie, 75232 Paris Cedex 5, France
}

\begin{abstract}
A B S T R A C T
Molten fluorides are appealing coolants for innovative nuclear systems but structural alloys may undergo corrosion at high temperature. Because corrosion primarily occurs via electrochemical reactions, electrochemical techniques are ideal for the study of corrosion thermochemistry and kinetics. Examples are given. An electrochemical series was established using voltammetry in LiF-NaF at $1173 \mathrm{~K}$. Stability increases in the following order: $\mathrm{Na}, \mathrm{Cr}, \mathrm{Fe}, \mathrm{Ni}, \mathrm{Mo} / \mathrm{W}, \mathrm{Ag}$, Au. Various alloys were also classified according to their oxidation resistance. A cathodic protection method was developed to curb the intergranular attack of some nickel alloys in molten $\mathrm{LiF}-\mathrm{CaF}_{2}-\mathrm{MgF}_{2}-\mathrm{ZrF}_{4}$ containing tellurium vapor at $953 \mathrm{~K}$. Voltammetry and polarization resistance measurement were used to estimate the rate of chromium selective dissolution for nickel base alloys immersed in LiF-NaF at $1073 \mathrm{~K}$ and $1173 \mathrm{~K}$.
\end{abstract}

\section{Introduction}

Many molten fluoride salts have good heat transfer properties, have low vapor pressures with boiling points in excess of $1600 \mathrm{~K}$, are stable in radiation fields, and can dissolve high concentrations of actinides and fission products. As a consequence, such salts are potentially of interest for innovative nuclear systems either for heat-transfer applications (only), as the liquid fuel of a Molten Salt Reactor (MSR), for pyrochemical reprocessing or for cooling inertial and magnetic fusion energy systems. Corrosion is the most unique and critical requirement on structural metallic materials, since many alloys might experience significant corrosion at high temperature (above approx. $973 \mathrm{~K}$ ) when the molten salt chemistry is not carefully controlled.

Corrosion of metals in fluoride salts was investigated for MSRs' development as early as 1950 [1]. Various alloys were tested in mixtures of $\mathrm{LiF}, \mathrm{BeF}_{2}, \mathrm{NaF}, \mathrm{ZrF}_{4}, \mathrm{ThF}_{4}, \mathrm{NaBF}_{4}$, etc., up to about $1088 \mathrm{~K}$ using static experiments, convection loops and in-pile surveillance specimens; nickel alloys appeared to be more suitable than iron steels $[2,3]$. Corrosion originates from an electronic exchange between the metallic material and an oxidant from the bath. Because the reaction constants depend on temperature, mass

\footnotetext{
* Corresponding author. Tel.: +33 1690816 15; fax: +33 169081586 .

E-mail address: celine.cabet@cea.fr (C. Cabet).

${ }^{1}$ Current address: Millipore SAS, Bioscience Division, BP 307, 78054 Saint-Quentinen-Yvelines Cedex, France.

${ }^{2}$ Current address: Westinghouse Electric Company, Nuclear Services, SE-721 63 Västerås, Sweden.
}

transfer will occur in any circuit with a thermal gradient: alloy dissolved from hotter zones, will be transported by convection, and then plated to colder areas. Mass transfer is a complex process involving several elementary or coupled steps such as solid diffusion, electronic transfer, and diffusion in the liquid phase. However, corrosion itself is essentially an electrochemical process.

Electrochemical methods have been developed for studying chemical processes in fluoride salts for years with applications in determining oxidation states, reaction paths and rates, speciation, solubility, etc., and some industrial electrolytic processes use molten fluoride media, for example for electrowinning of aluminum or electrodeposition of $\mathrm{Ti}, \mathrm{Ta}$ and $\mathrm{Nb}$ on valves, and in the nuclear industry, for electrorefining of spent fuel [4-7].

This paper illustrates the potential of using electrochemistry in the study of thermodynamics and kinetics of corrosion reactions in molten fluoride baths. Two selected examples focused on $\mathrm{Ni}$ base alloys (corrosion in a model LiF-NaF media and Te attack in LiF$\left.\mathrm{CaF}_{2}-\mathrm{MgF}_{2}-\mathrm{ZrF}_{4}\right)$ highlight the benefits of such versatile, efficient, compact and fast experiments, and acknowledges the challenges when more complex systems are involved.

\section{Experimental}

\subsection{Apparatus}

Experiments were conducted in a gas-tight container made of stainless steel or Inconel 600 with a glassy carbon crucible or an alumina crucible (test with tellurium). About $200 \mathrm{~g}$ of the salt 


\section{Nomenclature}

$a(\mathrm{Cr}) \quad$ activity of $\mathrm{M}$, depends on $T$

$E_{\text {ox }}(\mathrm{M})$ apparent oxidation potential of the metal $\mathrm{M}(\mathrm{V})$ as defined in Section 3.2, depends on $T$

$E^{\circ}\left(\mathrm{M} / \mathrm{MF}_{n}\right)$ standard redox potential of the redox couple $\mathrm{M} / \mathrm{MF}_{n}$ (V), depends on $T$

$D(\mathrm{M}) \quad$ diffusion coefficient of $\mathrm{M}$ in the given medium, depends on $T$ $n$

$\mathrm{F}$

$R$

$T$ number of electrons exchanged in an electrode reaction or an electrochemical reaction

Faraday constant (96485 C)

gas constant $\left(8.314 \mathrm{~J} \mathrm{~mol}^{-1} \mathrm{~K}^{-1}\right)$

temperature $(\mathrm{K})$ mixture was used under a flow of dry argon or dry nitrogen. The container was placed into a small well-type furnace with all heat-sensitive parts - gaskets, O-rings, connections - kept out of the hot zone. The temperature was calibrated before the tests using K-type thermocouples.

\subsection{Materials and electrodes}

A three-electrode cell was used and connected to a potentiostat. Each electrode was connected to a current collector made of an Inconel 600 rod or a platinum wire and then enclosed into an alumina tube (for electrical insulation).

Working electrodes were made of wires or rectangular or cylindrical metallic pieces. Wires of $\mathrm{Pt}, \mathrm{Ag}, \mathrm{Au}, \mathrm{Fe}, \mathrm{Ni}, \mathrm{Mo}, \mathrm{W}, \mathrm{Ni}-$ 11 at.\%Cr and $\mathrm{Ni}-22$ at.\%Cr were supplied from Goodfellow (purity higher than $99.95 \%, 1 \mathrm{~mm}$ diameter). $\mathrm{Ni}-\mathrm{Cr}$ alloy ingots with 11 , 22,33 and 53 at.\% $\mathrm{Cr}$ were made at Commissariat a l'Energie atomique et aux energies alternatives, France by fusion of the elementary powders. Ni-22Cr-14 W was produced at Ecole Nationale Supérieure des Mines de Saint Etienne, France from the fusion of the metallic powder in a cold crucible. $\mathrm{Ni}-16 \mathrm{Mo}-7 \mathrm{Cr}-2 \mathrm{Fe}$ was manufactured by Skoda NM, Czech Republic. Commercial sheets of Alloy C276 (Ni-17Mo-16CrFeWMn) and Alloy C22 (Ni-22Cr$13 \mathrm{Mo}-3 \mathrm{~W}-3 \mathrm{Fe}$ ) were also used. The immersed electrode length was usually of about $10 \mathrm{~mm}$.

Three millimeter diameter vitreous carbon rods and $50 \mathrm{~mm}^{2}$ platinum plates were used as counter electrodes.

Pseudo-reference electrodes made of a $1 \mathrm{~mm}$ diameter platinum wire (purity: 99.99\%) and reference electrodes based on the $\mathrm{Ni} / \mathrm{Ni}^{\mathrm{II}}$ system (a Ni wire dipping into a salt mixture with $10^{-3} \mathrm{~g} \mathrm{Ni}^{\mathrm{II}}$ ions $/ \mathrm{kg}$ is enclosed in a BN crucible drilled with a $1 \mathrm{~mm}$ hole) were used. Both systems were observed to enable for stable and reproducible potential measurements for at least 2 weeks when the salt chemistry was kept constant. (Pseudo) reference electrodes were shown to go back to their initial potentials after a polarization had been applied. Note that potentials obtained versus the pseudo-reference can be compared neither with thermochemical calculations, nor with measured potentials using the $\mathrm{Ni} / \mathrm{Ni}^{\mathrm{II}}$ reference. However, the platinum wire has a straightforward layout making it a good choice for a first, global and fast assessment of a system.

\subsection{Salt mixtures}

Two fluoride mixtures were investigated at temperatures ranging from $953 \mathrm{~K}$ to $1373 \mathrm{~K}$. High purity reactants (purity > 99.95\%) were mixed and the powder was stored in a drying oven; Table 1 gives test temperatures and salt compositions.

Salt mixtures were slowly heated under vacuum from room temperature up to $20 \mathrm{~K}$ below the theoretical melting temperature. Then argon (Air Liquide, Alpha gaz $\mathrm{Ar} 2$ certified with $\mathrm{O}_{2}<100 \mathrm{ppb}$ and $\mathrm{H}_{2} \mathrm{O}<500 \mathrm{ppb}$; flow around $10 \mathrm{~L} \mathrm{Ar} / \mathrm{h}$ ) was flushed into the system and the heating resumed up to the test temperature. The overall heating procedure lasted for approx. 2 days. Eventually, the electrodes were lowered into the melt and testing started. Initial concentration of oxygen ions in the melt was determined by voltammetry on an Au electrode using a calibration curve. Typically the initial oxygen concentration in $\mathrm{LiF}-\mathrm{NaF}$ at $1173 \mathrm{~K}$ was around $2.510^{-3} \mathrm{~mol} \mathrm{~kg}^{-1}$.

\section{Thermochemical properties of metals in a model fluoride melt}

As will be described in more detailed, electrochemistry is envisioned as a tool to study the fundamentals of metal/salt interactions. The present work is thus limited to transient methods or short duration tests with small amounts of salts and little metallic electrodes. It also uses simple - binary to quaternary - fluoride salt mixtures.

\subsection{Practicability of electrochemical techniques in a binary molten fluoride}

Fig. 1a illustrates cyclic voltammetry in LiF-NaF at $1173 \mathrm{~K}$ using a silver working electrode versus a platinum pseudo-reference (and glassy carbon as CE). Scanning was applied from the open-circuit potential toward anodic potentials, then toward cathodic potentials, and eventually back to the open-circuit potential. The voltammogram shows two marked increases: at approx. $+1.1 \mathrm{~V}$ on the anodic side and at approx. $-1.4 \mathrm{~V}$ on the cathodic side. The increase in the anodic current density is steep and application of higher overpotentials showed no further limitation. Therefore, this current results from oxidation of a major component. Based on thermochemical calculations (see Section 3.2), it was assumed that the increase in the current density is only due to the anodic dissolution of the electrode metal according to:

$\mathrm{Ag} \rightarrow \mathrm{Ag}^{\mathrm{I}}+\mathrm{e}^{-}$

It has been largely discussed $[7,8]$ that cations in the melt should be associated with fluoride ions to form complexes although the exact coordination - likely to depend on the exact salt mixture - is unknown. Thus, reaction (1) can be written considering formation of a fluoride compound:

$\mathrm{Ag}+\mathrm{F}^{-} \rightarrow \mathrm{AgF}+\mathrm{e}^{-}$

The cathodic current density is also steep and non-diffusion limited, corresponding to reduction of a major element in the bath. Thermochemical calculations concluded that $\mathrm{Na}^{\mathrm{I}}$ ions - not $\mathrm{Li}^{\mathrm{I}}$ ions - are to be first reduced, following the electrode reaction:

$\mathrm{Na}^{\mathrm{l}}+\mathrm{e}^{-} \rightarrow \mathrm{Na}$

Between the anodic and cathodic peaks, the residual current density is of $0.5 \mathrm{~mA} \mathrm{~cm}^{-2}$ maximum, indicating the virtual absence of any other reactive species. The electro-stability window for LiF$\mathrm{NaF}$ with a silver electrode extends over approx. $2.5 \mathrm{~V}$ at $1173 \mathrm{~K}$. 
Table 1

Test temperature and chemical composition of the salt mixtures.

\begin{tabular}{|c|c|c|c|c|c|c|c|c|c|}
\hline & \multicolumn{2}{|c|}{ Temperature (K) } & \multicolumn{6}{|c|}{ Compound (mol\%) } & \multirow[t]{2}{*}{ Residual oxygen conten } \\
\hline & Melting & Test & $\mathrm{LiF}$ & $\mathrm{NaF}$ & $\mathrm{CaF}_{2}$ & $\mathrm{MgF}_{2}$ & $\mathrm{ZrF}_{4}$ & Impurities & \\
\hline LiF-NaF & 922 & $1073-1373$ & 61 & 39 & & & & $<0.05$ & $2.5 \times 10^{-3} \mathrm{~mol} \mathrm{~kg}^{-1}$ \\
\hline $\mathrm{LiF}-\mathrm{CaF}_{2}-\mathrm{MgF}_{2}-\mathrm{ZrF}_{4}$ & $\sim 823$ & 953 & 54 & & 10.8 & 25.2 & 10 & $<0.05$ & Not measured \\
\hline
\end{tabular}

During linear sweep voltammetry in the anodic domain, oxidation of silver following reaction (1) is associated to reduction of $\mathrm{Na}^{\mathrm{I}}$ ions at the counter-electrode according to reaction (3). When the working electrode is polarized in the cathodic domain, oxidation of the counter-electrode carbon should produce gaseous $\mathrm{CF}_{4}$. In Sections 3.2 and 3.3, potentials are virtually referenced to the $\mathrm{Na} / \mathrm{Na}^{\mathrm{I}}$ redox couple (the Pt pseudo-reference electrode takes an unknown potential in LiF-NaF, understood to be constant in a given medium; assuming that the reduction of $\mathrm{Na}^{\mathrm{l}}$ ions at the working electrode surface is independent of the electrode material, the voltammograms are "positioned" toward the potential axis considering that the apparent reduction potential of $\mathrm{Na}^{\mathrm{I}}$ ions occurs at $-1.4 \mathrm{~V}$ (whatever the test conditions) and to $\mathrm{Ni} / \mathrm{Ni}^{\mathrm{II}}$.

Although Fig. 1 shows that oxidation of fluoride ions is not practically achievable in the tested salt mixture, $\mathrm{F}^{-} / \mathrm{F}_{2}$ (gas) is the most largely used reference redox couple in molten fluoride with the corresponding electrode reaction being [9]:

$2 \mathrm{~F}^{-} \rightarrow \mathrm{F}_{2}$ (gas) $+2 \mathrm{e}^{-}$

An equivalent voltammogram is shown in Fig. 1b for gold. Oxidation occurs at an even more anodic potential (approx. $2.5 \mathrm{~V}$ ) further expanding the electrostability window over $3.5 \mathrm{~V}$. Interestingly, evidence was obtained (no gas formation) that the anodic current actually relates to oxidation of gold - and not of fluoride ions - according to the electrode reaction:

$\mathrm{Au}+3 \mathrm{~F}^{-} \rightarrow \mathrm{AuF}_{3}+3 \mathrm{e}^{-}$

Note that cathodic polarization must be avoided to prevent formation of $\mathrm{Au}_{2} \mathrm{Na}$ intermetallic compound.

The shape of the curves in Fig. $1 \mathrm{a}$ and $\mathrm{b}$ were observed to be highly reproducible although the use of a pseudo-reference induced a shift in the actual potential values.

LiF-NaF electro-stability window at $1173 \mathrm{~K}$ extends over approx. $2.5 \mathrm{~V}$ with a silver electrode, and further toward anodic potentials with a gold electrode, enabling for utilization of electrochemical techniques in a broad potential range.

\subsection{Determination of oxidation potential of pure metals using voltammetry}

Jenkins and collaborators [10], Grjotheim [11], De Van [12], and Williams and collaborators [13] reported measurements of metal oxidation potentials using voltammetry techniques respectively in LiF-NaF-KF and $\mathrm{LiF}-\mathrm{BeF}_{2}-\mathrm{ZrF}_{4}$ at $773 \mathrm{~K}, \mathrm{NaF}-\mathrm{KF}$ at $1123 \mathrm{~K}$, $\mathrm{LiF}-\mathrm{BeF}_{2}$ at $873 \mathrm{~K}$ and $\mathrm{NaF}-\mathrm{AlF}_{3}$ at $1273 \mathrm{~K}$. Such measurements enable to set experimental stability series. This approach was used in the present work to rank various metals according to their redox potential in LiF-NaF at $1173 \mathrm{~K}$ [14]. Potentials were linearly scanned $(1 \mathrm{mV} / \mathrm{s})$ from the open-circuit potential toward anodic potentials, and then, from the open-circuit potential toward cathodic potentials.

Fig. 1c plots voltammograms recorded with $\mathrm{Cr}, \mathrm{Fe}, \mathrm{Ni}$, Mo and $\mathrm{W}$ electrodes in LiF-NaF at $1173 \mathrm{~K}$. The curves in Fig. 1c were shown to be repeatable with the exact potential values changing due to the use of a pseudo-reference. For all metals, the increase in cathodic density occurs with a similar slope. It was assumed that it should correspond to reduction of the $\mathrm{Na}^{\mathrm{l}}$ ions. Thus, the curves in Fig. 1c have been shifted along the potential axis so that cathodic current curves overlay (with apparent reduction of $\mathrm{Na}^{\mathrm{I}}$ ions at $-1.4 \mathrm{~V}$ ). Oxidation in Fig. 1c falls within the domain of solvent stability and corresponds to a reaction involving the working electrode material. For all metals, the anodic current steeply increases; such a signal, without limitation, usually implies a direct dissolution of the electrode material into the solution. The electrode dissolution reaction may be written as:

$\mathrm{M}+n \mathrm{~F}^{-} \rightarrow \mathrm{MF}_{n}+n \mathrm{e}^{-}$

$\mathrm{M}$ is any of the following metals $\mathrm{Cr}, \mathrm{Fe}, \mathrm{Ni}, \mathrm{Mo}, \mathrm{W}, \mathrm{Ag}, \mathrm{Au}$ and $\mathrm{MF}_{n}$ the corresponding oxidation product whatever its exact speciation in the fluoride melt.

The curves in Fig. 1 made it possible to estimate an apparent oxidation potential for electrode reaction (6) by measuring the potential at the base of the anodic current increase. Table 2 lists these experimental oxidation potentials $E_{\text {ox }}(\mathrm{M})$ determined for $\mathrm{Cr}, \mathrm{Fe}, \mathrm{Ni}$, $\mathrm{Mo}, \mathrm{W}, \mathrm{Ag}$ and $\mathrm{Au}$ versus the pseudo-reference Pt electrode (with the apparent reduction of $\mathrm{Na}^{\mathrm{I}}$ ions assumed to occur at $-1.4 \mathrm{~V}$ ). In a tentative comparison of the present set of data to published potentials for other fluoride media, Table 3 reports the results from Table 2 and from Refs. [10-13] with all potentials being referenced to nickel oxidation.

In addition, theoretical standard redox potentials were estimated at $1173 \mathrm{~K}$ based on the Gibbs free energies of reaction for pure substances. $\Delta_{\mathrm{r}} G^{\circ}$ for reaction (7) was computed using tabulated thermochemical data from [15]:

$\mathrm{M}(\mathrm{s})+n / 2 \mathrm{NiF}_{2}(\mathrm{~s}) \rightarrow \mathrm{MF}_{n}(\mathrm{~s})+n / 2 \mathrm{Ni}(\mathrm{s})$

Then the standard redox potential for $\mathrm{M} / \mathrm{MF}_{n}$ was calculated from:

$\Delta_{r} G^{\mathrm{o}}(\mathrm{T})=-n \cdot \mathrm{F} \cdot\left[\mathrm{E}^{\mathrm{o}}\left(\mathrm{M} / \mathrm{MF}_{n}\right)-\mathrm{E}^{\mathrm{o}}\left(\mathrm{Ni} / \mathrm{NiF}_{2}\right)\right]$

with $E^{\circ}\left(\mathrm{Ni} / \mathrm{NiF}_{2}\right)=0 \mathrm{~V}$.

Most metals form several fluoride complexes with various stoichiometry. Based on $\Delta G^{\circ}$, it was estimated that $\mathrm{CrF}_{2}, \mathrm{FeF}_{2}, \mathrm{NiF}_{2}$, $\mathrm{MoF}_{3}, \mathrm{WF}_{4}, \mathrm{AgF}, \mathrm{AuF}_{3}$ should be the stable fluoride compounds.

Note that the previous calculation using data for pure substances disregards any solvation process taking place in the melt, i.e. any compound whether pure or in solution was considered to be at unit activity. Considering this major approximation, it was stated that the standard redox potentials, listed in Table 3 for $T=1173 \mathrm{~K}$, are rough estimates of redox potentials. Due to complexation, activity of a dissolved species is lower than one and so calculated standard redox potentials are overestimation of actual experimental redox potentials.

For a given metal in Table 3, the redox potential value largely varies from one source to another, since experimental conditions are widespread in terms of temperature and salt composition. Nevertheless, the data show a fair agreement on the potential ranking. It implies that temperature might have equivalent effect on the Gibbs free energies of formation of the metallic fluorides. Besides, activity coefficients of dissolved $\mathrm{Cr}, \mathrm{Fe}, \mathrm{Ni}, \mathrm{W}$ and Mo compounds should vary in the same way when changing from one particular salt mixture to another. Part of the discrepancy in the theoretical and experimental data for $\mathrm{W}$ and Mo, may be attributed to inappropriate selection of the stable fluoride compound $\left(\mathrm{WF}_{6}\right.$ and 

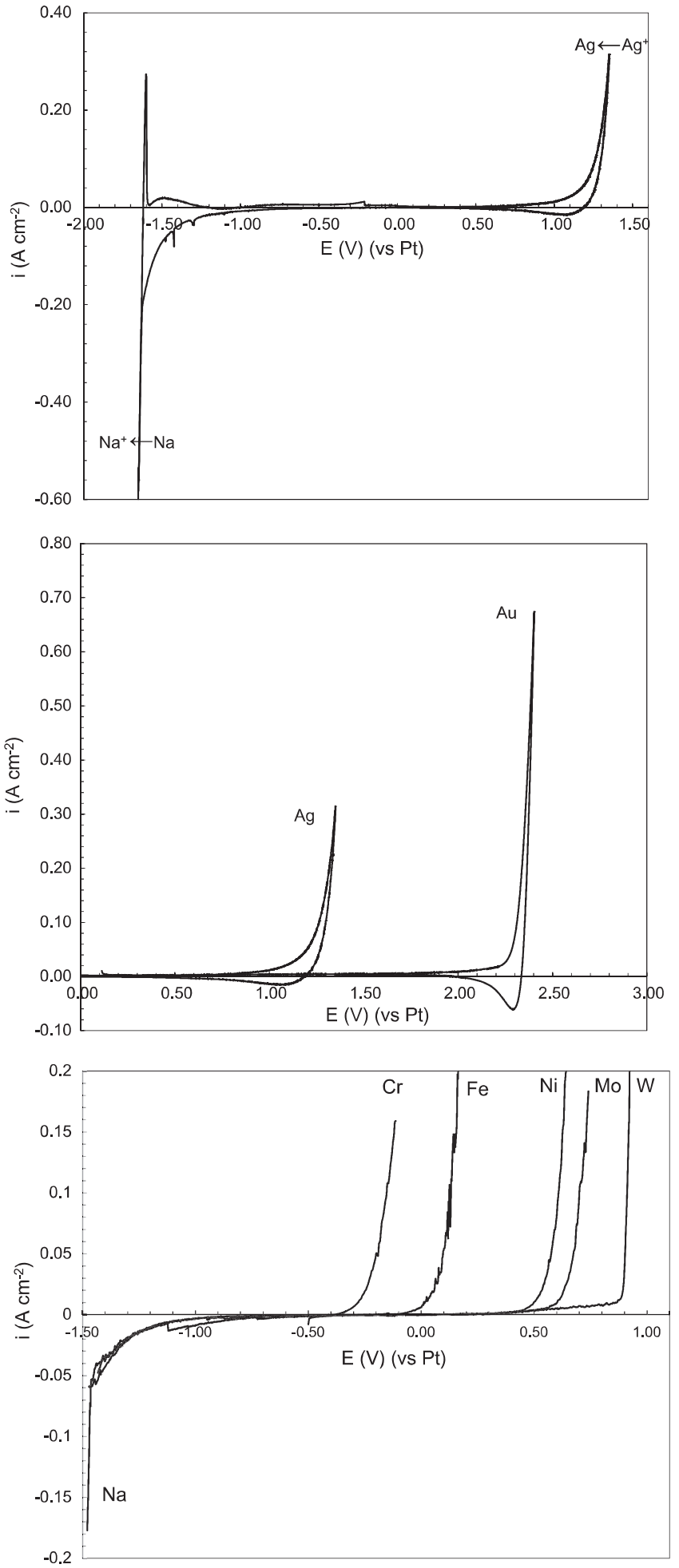

Fig. 1. Voltammetry in LiF-NaF at $1173 \mathrm{~K}$ : (a) cyclic linear sweep on $\mathrm{Ag}$ (scan rate: $100 \mathrm{mV} \mathrm{s}^{-1}$; scanning from open-circuit potential toward anodic potentials, then toward cathodic potentials, and back to open-circuit potential); (b) cyclic linear sweep on $\mathrm{Ag}$ and $\mathrm{Au}$ (scan rate: $100 \mathrm{mV} \mathrm{s}^{-1}$; scanning from open-circuit potential toward anodic potentials, and back to open-circuit potential; cathodic polarization of Au was purposely avoided); (c) linear sweep on $\mathrm{Cr}$, Fe, Ni, Mo and W (scan rate: $1 \mathrm{mV} \mathrm{s}^{-1}$; scanning from open-circuit potential toward anodic potentials, then back to open-circuit potential and eventually scanning toward cathodic potentials, and back to open-circuit potential).

$\mathrm{MoF}_{3}$ ). Mo and $\mathrm{W}$ actually form numerous fluoride complexes, with coordination ranging from 2 to 6 . The oxidation state in
Table 2

Experimental oxidation potentials of metals versus the Pt pseudo-reference electrode in LiF-NaF at $1173 \mathrm{~K}$.

\begin{tabular}{lllllllll}
\hline & $\mathrm{Na}$ & $\mathrm{Cr}$ & $\mathrm{Fe}$ & $\mathrm{Ni}$ & $\mathrm{Mo}$ & $\mathrm{W}$ & $\mathrm{Ag}$ & $\mathrm{Au}$ \\
\hline$E_{\mathrm{ox}}^{*} / \mathrm{Pt}(\mathrm{V})$ & -1.40 & -0.22 & +0.04 & +0.46 & +0.65 & +0.90 & +1.10 & +2.15 \\
\hline
\end{tabular}

fluoride melt might be different from what has been implied from calculations based on the data for pure solids and gasses.

Linear voltammetry was shown to be a fast and reliable method to classify metallic elements according to their oxidation stability in a particular molten salt. Although the value of redox potential is dependent on the electrolyte properties, ranking of metals is consistent from one LiF-base melt to another: $\mathrm{Cr}$ is the least stable metal in molten fluoride, then $\mathrm{Ni}, \mathrm{Mo}$ and $\mathrm{W}$, and then $\mathrm{Ag}$ and $\mathrm{Au}$. However, capability of the voltammetry is limited when the salt mixture is more complex, especially if it contains electroactive species. In addition, the equilibrium potential of the salt mixture as well as the actual oxidant species responsible for oxidation of metals in molten fluoride remains unknown, restricting a complete description of the metal/salt system.

\subsection{Application of the method to the study of binary NiCr alloys}

Voltammetry was used in LiF-NaF at $1173 \mathrm{~K}$ for $\mathrm{Ni}_{1-x} \mathrm{Cr}_{x}$ alloys with $x$ ranging from 0.11 to 0.53 . Fig. 2 shows the curves obtained for the binary alloys, as well as for pure $\mathrm{Ni}$ and $\mathrm{Cr}$; the voltammograms have been overlaid with the reduction of $\mathrm{Na}^{\mathrm{I}}$ ions at $-1.4 \mathrm{~V}$. As in Fig. 1c, a sharp increase in current density indicates material oxidation. Apparent oxidation potentials of $\mathrm{Ni}_{1-x} \mathrm{Cr}_{x}$ electrodes are situated between the oxidation potentials of pure $\mathrm{Cr}$ and pure $\mathrm{Ni}$, and they increase with decreasing $x$. For $x$ higher than 0.2 , the voltammograms show a two-stage oxidation process. The first increase in the current density may originate from the selective dissolution of $\mathrm{Cr}$ and the second from the congruent dissolution of $\mathrm{Cr}$ and $\mathrm{Ni}$ as expected when an anodic polarization is applied to a solid solution made of two metals $[16,17]$. The voltammogram for alloy $\mathrm{Ni}-22 \mathrm{Cr}$ exhibits a plateau that was attributed to the solid state diffusion of $\mathrm{Cr}$ to the electrode surface to be oxidized. This indicates that the linear sweep rate is appropriate. Use of a slower sweep may allow development of a plateau for alloy $\mathrm{Ni}-33 \mathrm{Cr}$ as well. The apparent oxidation potentials, called $E_{\mathrm{ox}}(\mathrm{Cr})$ and $E_{\text {ox }}(\mathrm{Ni}-\mathrm{Cr})$, were measured in Fig. 2 and are given in Table 4. Selective dissolution of chromium was verified by polarizing a $\mathrm{Ni}-22 \mathrm{Cr}$ electrode at $-0.1 \mathrm{~V}$ versus $\mathrm{Pt}$ for $3600 \mathrm{~s}$ (potential between $E_{\mathrm{ox}}(\mathrm{Cr})$ and $\left.E_{\mathrm{ox}}(\mathrm{Ni}-\mathrm{Cr})\right)$ in $\mathrm{LiF}-\mathrm{NaF}$ at $1173 \mathrm{~K}$. Post-test SEM examination and EDS analysis showed $\mathrm{Cr}$ depletion and pore condensation at the alloy surface up to about $100 \mu \mathrm{m}$.

The system thermochemistry was assessed by taking into account the mixing effect in the metallic solid solution $\mathrm{Ni}-\mathrm{Cr}$. As was previously stated in Section 3.2, evaluation of the components of the liquid salt phase is based on the data for pure substances (neglecting the important effect of solvation). The Ni-Cr phase diagram shows that alloys with $x$ higher than 0.42 should be twophased at $1173 \mathrm{~K}$ [18]. Therefore, only $\mathrm{Ni}_{1-x} \mathrm{Cr}_{x}$ alloys with $x<0.42$ were further considered. $\Delta G_{\mathrm{f}}$ was calculated for the following reaction:

$\mathrm{Cr}^{\text {alloy }}(\mathrm{s})+\mathrm{F}_{2}$ (gas) $\rightarrow \mathrm{CrF}_{2}$ (s)

The electrochemical reaction is given by:

$\mathrm{Cr}^{\text {alloy }}(\mathrm{s})+2 \mathrm{~F}^{-} \rightarrow \mathrm{CrF}_{2}(\mathrm{~s})+2 \mathrm{e}^{-}$

The theoretical oxidation potential for selective dissolution of $\mathrm{Cr}$ from the alloy is calculated from the Nernst equation: 
Table 3

Oxidation potentials of metals referenced to $\mathrm{Ni} / \mathrm{NiF}_{2}$ (in $\mathrm{V}$ ) [10-13].

\begin{tabular}{|c|c|c|c|c|c|c|c|c|c|c|c|}
\hline & Temperature (K) & Medium & $\mathrm{Na}$ & $\mathrm{Cr}$ & $\mathrm{Fe}$ & $\mathrm{Ni}$ & W & Mo & $\mathrm{Ag}$ & $\mathrm{Au}$ & $\mathrm{F}^{-}$ \\
\hline Jenkins et al. [10] & 773 & LiF-NaF-KF & & -0.70 & -0.41 & 0 & & & & & \\
\hline Jenkins et al. [10] & 773 & $\mathrm{LiF}-\mathrm{BeF}_{2}-\mathrm{ZrF}_{4}$ & & & -0.39 & 0 & & & & & \\
\hline De Van [12] & 873 & $\mathrm{LiF}-\mathrm{BeF}_{2}$ & & -0.83 & 0.46 & 0 & & & & & \\
\hline Grjotheim [11] & 1123 & $\mathrm{NaF}-\mathrm{KF}$ & & -0.70 & -0.12 & 0 & & & & & \\
\hline $\begin{array}{l}\text { This work, experimental } \\
\text { This work, computed }\end{array}$ & 1173 & LiF-NaF & -1.86 & -0.68 & -0.42 & 0 & +0.44 & +0.19 & +0.52 & +1.57 & \\
\hline$E^{\circ}\left(\mathrm{M} / \mathrm{MF}_{n}\right)$ & 1173 & Hypothetical (pure substances) & -2.23 & -0.80 & -0.41 & 0 & +0.05 & +0.23 & +0.99 & +2.02 & +2.46 \\
\hline Willams et al. [13] & 1273 & $\mathrm{NaF}-\mathrm{AlF}_{3}$ & & & -0.55 & 0 & +0.20 & & & & \\
\hline
\end{tabular}

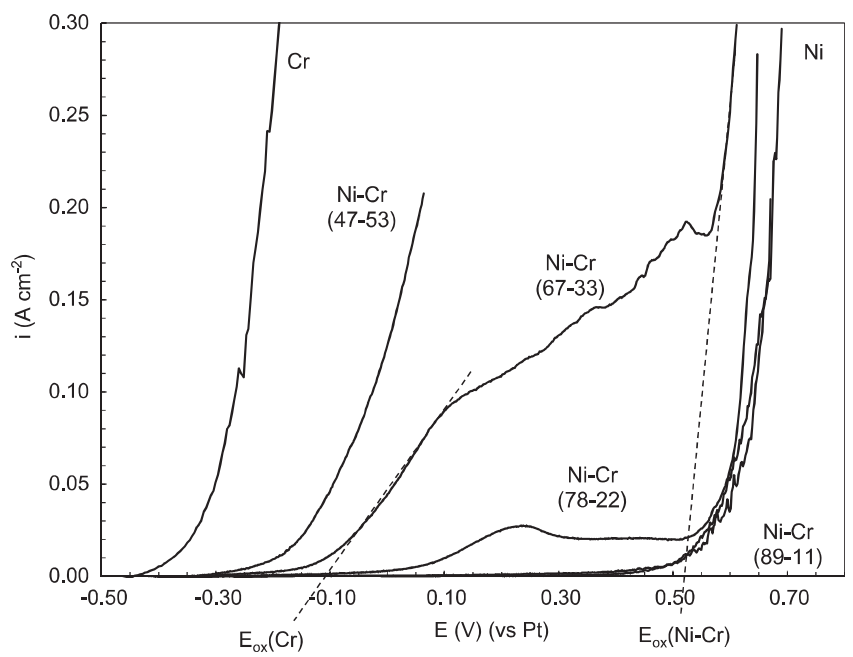

Fig. 2. Linear sweep voltammetry in $\mathrm{LiF}-\mathrm{NaF}$ at $1173 \mathrm{~K}$ on $\mathrm{Cr}, \mathrm{Ni}$ and $\mathrm{Ni}-\mathrm{Cr}$ alloys (scan rate: $1 \mathrm{mV} \mathrm{s}^{-1}$; scanning from open-circuit potential toward anodic potentials).

\section{Table 4}

Experimental oxidation potentials for selective dissolution of $\mathrm{Cr}$ and concurrent dissolution of $\mathrm{Cr}$ and $\mathrm{Ni}$ from the $\mathrm{Ni}_{1-x} \mathrm{Cr}_{x}$ electrodes in $\mathrm{LiF}-\mathrm{NaF}$ at $1173 \mathrm{~K}$ (versus $\mathrm{Pt}$ in V) [18].

\begin{tabular}{llll}
\hline Material & $x$ & $E_{\text {ox }}\left(\mathrm{Cr}^{\text {alloy }}\right)$ & $E_{\text {ox }}\left(\mathrm{NiCr}^{\text {alloy }}\right)$ \\
\hline Pure $\mathrm{Ni}$ & 0 & & 0.70 \\
$\mathrm{Ni}-10 \mathrm{Cr}$ & 0.1 & $0.20 \pm 0.10$ & 0.70 \\
$\mathrm{Ni}-20 \mathrm{Cr}$ & 0.2 & 0.10 & 0.67 \\
$\mathrm{Ni}-30 \mathrm{Cr}$ & 0.3 & -0.07 & 0.59 \\
$\mathrm{Ni}-50 \mathrm{Cr}$ & 0.5 & -0.18 & \\
Pure $\mathrm{Cr}$ & 1 & -0.23 & \\
\hline
\end{tabular}

$$
\begin{aligned}
E_{\mathrm{ox}}^{\text {hypo }}\left(\mathrm{Cr}^{\text {alloy }}\right)\left(\text { versus } \mathrm{F}^{-} / \mathrm{F}_{2}\right)= & E^{\circ}+\frac{2.3 R T}{2 \mathrm{~F}} \\
& \times \log \frac{a\left(\mathrm{CrF}_{2}\right)}{a\left(\mathrm{Cr}^{\text {alloy }}\right) \cdot a\left(\mathrm{~F}^{-}\right)^{2}} \\
= & \frac{\Delta G_{\mathrm{f}}^{\mathrm{o}}\left(\mathrm{CrF}_{2}\right)}{2 \mathrm{~F}}-\frac{2.3 R T}{2 \mathrm{~F}} \\
& \times \log \left[a\left(\mathrm{Cr}^{\text {alloy }}\right)\right]
\end{aligned}
$$

considering $a\left(\mathrm{CrF}_{2}\right)=1$ and $a\left(\mathrm{~F}^{-}\right)=1$. The $\mathrm{Cr}$ activity in the $\mathrm{Ni}_{1-x} \mathrm{Cr}_{x}$ alloy was computed using the FactSage SGTE alloy database [19]. $E^{\circ}$ is calculated considering the redox system $\mathrm{F}_{2}(1 \mathrm{~atm}) / \mathrm{F}^{-}(a=1)$ as the reference.

The same calculation was performed for the concurrent dissolution of both elements from the alloy presuming:

$$
\begin{gathered}
(1-x) \mathrm{Ni}^{\text {alloy }}(\mathrm{s})+x \mathrm{Cr}^{\text {alloy }}(\mathrm{s})+\mathrm{F}_{2}(\text { gas }) \\
\rightarrow(1-x) \mathrm{NiF}_{2}(\mathrm{~s})+x \mathrm{CrF}_{2}(\mathrm{~s})
\end{gathered}
$$

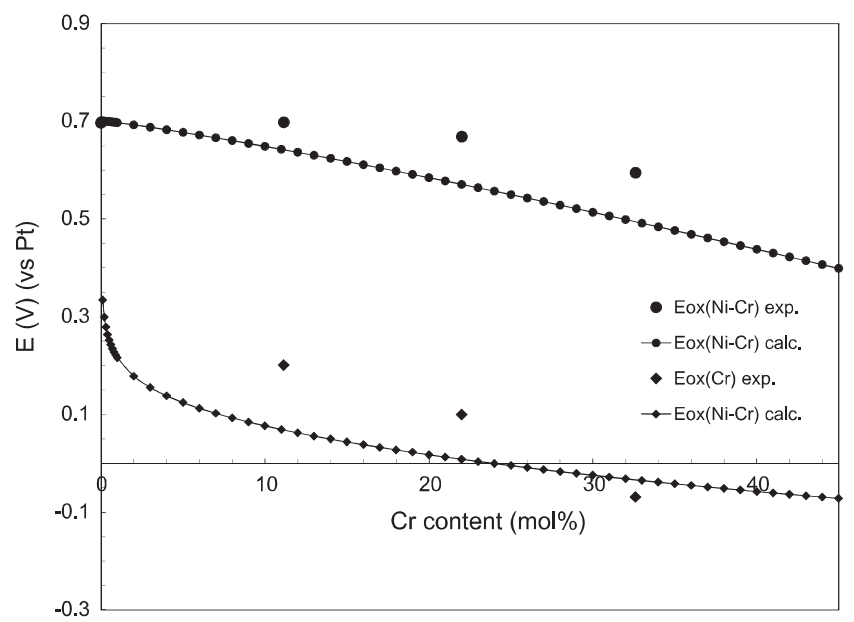

Fig. 3. Change in oxidation potentials as a function of $x$ for $\mathrm{Ni}_{1-x} \mathrm{Cr}_{x}$ alloys in LiF$\mathrm{NaF}$ at $1173 \mathrm{~K}$ : comparison of thermochemical calculations and experimental results.

Fig. 3 shows the experimental potentials versus Pt as from Table 4 together with the calculated potentials for reactions (10) and (12); the theoretical curves referenced to $\mathrm{F}^{-} / \mathrm{F}_{2}$ (gas) have been positioned using the experimental point of pure nickel. The shape of computed curves in Fig. 3 fairly fits evolution of experimental dissolution potentials considering the harsh hypotheses used in the previous calculation.

The method developed for pure metallic electrodes (see Section 3.2) was successfully applied to binary $\mathrm{NiCr}$ alloys in $\mathrm{LiF}-\mathrm{NaF}$ at $1173 \mathrm{~K} . E_{\text {ox }}\left(\mathrm{Cr}^{\text {alloy }}\right)$ being more electronegative than $E_{\mathrm{ox}}\left(\mathrm{Ni}-\mathrm{Cr}^{\text {alloy }}\right)$, a potential window exists in which $\mathrm{Cr}$ is selectively oxidized. Increase in the oxidation potential of $\mathrm{Ni}_{1-x} \mathrm{Cr}_{x}$ alloys with decreasing $x$ has been explained regarding the thermochemical properties of the $\mathrm{Ni}-\mathrm{Cr}$ solid solution (change in the chromium activity with $x$ and mixing effect). It was experimentally observed that $\mathrm{Cr}$-containing alloys exhibit poor corrosion resistance in molten fluorides [1-3]. Because $E_{\text {ox }}\left(\mathrm{Cr}^{\text {alloy }}\right)$ is related to $a\left(\mathrm{Cr}^{\text {alloy }}\right)$ by Eq. (10), the inequality $E_{\text {ox }}\left(\mathrm{Cr}^{\text {alloy }}\right)>E_{\text {ocp }}+0.5 \mathrm{~V}\left(E_{\text {ocp }}\right.$ being the bath equilibrium potential) induces that a critical $\mathrm{Cr}$ activity should exist. Any alloy with $a(\mathrm{Cr})$ lower than the critical value i.e. $a\left(\mathrm{Cr}^{\text {alloy }}\right)<\mathrm{a}^{*}$ may be stable in LiF-NaF, and other melts by analogy. However, the critical $\mathrm{Cr}$ activity remains virtually unknown.

\subsection{Study of more complex alloys}

Theoretically the developed method based on voltammetry is valid for any type of alloys. Fig. 4 shows voltammograms of ternary and multi-element nickel base alloys in LiF-NaF at $1073 \mathrm{~K}$. In practice however, it may be challenging to study analytically an alloy with a large number of elements due to many contributions to the current density as a function of potential. Anyway as illustrated 

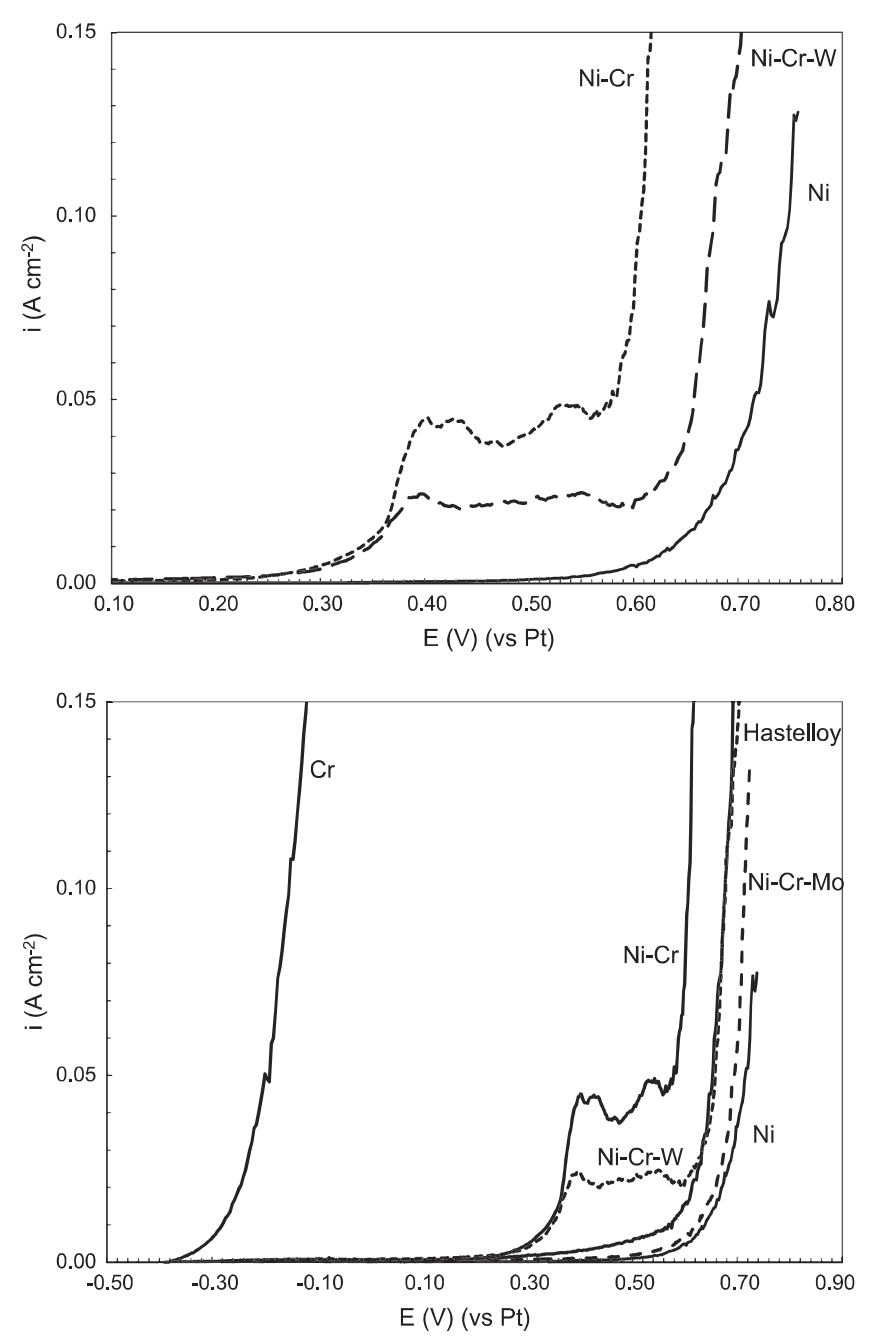

Fig. 4. Linear voltammetry in $\mathrm{LiF}-\mathrm{NaF}$ at $1073 \mathrm{~K}$ (scan rate: $0.5 \mathrm{mV} \mathrm{s}^{-1}$; scanning from open-circuit potential toward anodic potentials).

in Fig. 4, the alloy anodic dissolution starts between the dissolution of pure nickel and chromium, as was the case for binary alloys. Measurement of the first increase in current density, attributed to selective dissolution of chromium, allows classification of the alloys based on their chromium stability i.e. their oxidation resistance. Examinations of Alloy C276 specimens immersed at open-circuit potential for 7 and 14 days in LiF-NaF at $1073 \mathrm{~K}$ confirmed the selective oxidation of $\mathrm{Cr}$ and the formation of a Cr-depleted zone in the alloy. Essentially, evolution in the apparent oxidation potentials between the tested nickel base alloys is believed to originate from difference in the surface $\mathrm{Cr}$ activity which primarily depends on the alloy chromium content, but varies with the alloy composition and microstructure too, and is known to change during the corrosion processes due to $\mathrm{Cr}$-depletion. Interestingly, curves for alloys $\mathrm{Ni}-22 \mathrm{Cr}$ and $\mathrm{NiCrW}$ in Fig. $4 \mathrm{~b}$ show a plateau; the current density related to this plateau remained constant when the scan rate was lowered. It was assumed that the current density is limited due to diffusion in the solid phase. In that case, the limiting current density $i_{\lim }\left(\mathrm{A} \mathrm{cm}^{-2}\right)$ should verify [20]:

$i_{\lim }=\frac{n \cdot \mathrm{F} \cdot a(\mathrm{Cr})^{\text {alloy }}}{\delta} D(\mathrm{Cr})$

in which $\delta$ is the diffusion length (assumed globally constant for a given linear sweep scan rate).
According to Eq. (13), two alloys with equivalent $\mathrm{Cr}$ activity may exhibit different current density plateau depending on their $\mathrm{Cr}$ diffusion coefficient. The finding that $i_{\lim }$ for $\mathrm{NiCrW}\left(22 \times 10^{-3}\right.$ $\left.\mathrm{A} \mathrm{cm}^{-2}\right)$ is about half that of $i_{\text {lim }}$ for $\mathrm{Ni22} C \mathrm{Cr}\left(44 \times 0^{-3} \mathrm{~A} \mathrm{~cm}^{-2}\right)$ is in good agreement with the diffusion being slower in $\mathrm{W}$ containing nickel base alloys [21].

Voltammetry appears to be a fast and efficient method to screen alloys: the more electropositive the apparent oxidation potential, the more dissolution resistant the material. Based on Section 3.3, it is thought that change in $E_{\mathrm{ox}}(\mathrm{Cr})$ from one alloy to another essentially relates to the surface $\mathrm{Cr}$ activity and the explanation should also be valid for $a(\mathrm{Fe})$ for iron-containing alloys w/o chromium. However, the quantitative understanding of alloys behavior is impeded because the equilibrium potential of the molten salt is currently unknown.

\section{Control of Te speciation using polarization}

Besides the electrochemical corrosion, Molten Salt Reactor metallic structures may also suffer from interactions with in-pile produced fission products which are carried away from the core by the molten fuel. Metallic tellurium was shown to be particularly corrosive as a low concentration can cause intergranular attack of alloys with a severe embrittlement $[22,23]$.

Experiments were designed to study the possibility of mitigating this particular type of damage through potential control. In the following, tellurium vapor was obtained by adding a drop of liquid tellurium at the bottom of an alumina crucible containing a model salt mixture of $\mathrm{LiF}-\mathrm{CaF}_{2}-\mathrm{MgF}_{2}-\mathrm{ZrF}_{4}$; the three-electrode cell was then used as with a $\mathrm{Ni} / \mathrm{Ni}^{\mathrm{II}}$ reference electrode and $\mathrm{Pt}$ as counter-electrode (see Section 2).

Fig. 5a illustrates the corrosion morphology of Alloy C22 (a nickel base alloy with 22 mass.\% $\mathrm{Cr}$ ) when immersed for 2 weeks at $953 \mathrm{~K}$ in $\mathrm{LiF}-\mathrm{CaF}_{2}-\mathrm{MgF}_{2}-\mathrm{ZrF}_{4}$ without tellurium. The specimen exhibits a significant electrochemical corrosion with selective
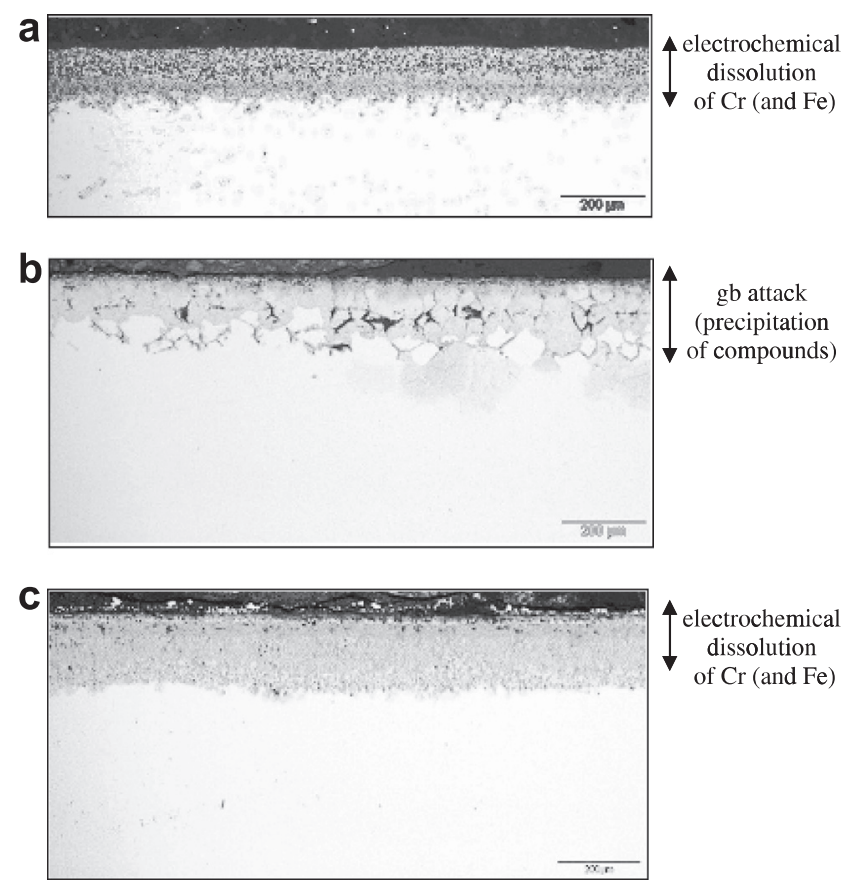

Fig. 5. Optical micrographs of Alloy $\mathrm{C} 22(\mathrm{Ni}-22 \mathrm{Cr}-14 \mathrm{Mo}-3 \mathrm{~W}-3 \mathrm{Fe})$ immersed for 2 weeks in $\mathrm{LiF}-\mathrm{CaF}_{2}-\mathrm{MgF}_{2}-\mathrm{ZrF}_{4}$ at $953 \mathrm{~K}$ : (a) no Te, no polarization, (b) with Te vapor, no polarization and (c) with Te vapor and polarization at $-3.4 \mathrm{~V}$ versus $\mathrm{F}^{-} / \mathrm{F}_{2}$ (gas). 
dissolution of $\mathrm{Cr}$ and $\mathrm{Fe}$. The high dissolution rate may be related to the high chromium content in the alloy (see Section 3) and to the use of an alumina crucible likely to introduce impurities in the melt (but $\mathrm{Al}_{2} \mathrm{O}_{3}$ does not interact with liquid tellurium). Fig. $5 \mathrm{~b}$ shows the specific effect of tellurium vapor with a marked intergranular attack. One should note that the observed attack is more severe than the attack seen in the MSRE or in experiments with a lower Te flux [23]. However, this acute intergranular damage helps in evidencing the attack thru short duration (2-week) immersion tests. Potential/activity diagrams in the systems $\mathrm{Te}-\mathrm{Zr}-\mathrm{Cr}-\mathrm{Ni}-$ Mo-F-O were computed at $953 \mathrm{~K}$ using data for pure substances from the HSC Chemistry database [15] and the hypotheses stated in Section 3.3. A computed diagram for $\mathrm{Zr}-\mathrm{Te}-\mathrm{F}-\mathrm{O}$ is shown in Fig. 6 together with the lines for $\mathrm{Ni} / \mathrm{Ni}_{2} \mathrm{Te}_{3}$ and $\mathrm{Mo} / \mathrm{Mo}_{3} \mathrm{Te}_{4}$. Fig. 6 shows a large stability domain for liquid tellurium ( 0 oxidation state) which overlaps the domains for stability of the mixed metal-Te compounds. Presuming tellurium vapor (not a stable phase at $953 \mathrm{~K}$ ) has the same properties as the liquid phase, the localized corrosion is thought to be due to the intergranular precipitation of brittle metallic telluride compounds. For longer exposures, tellurium atoms are likely to diffuse deeper along grain boundaries with an important impact on the alloy strength.

Analysis of Fig. 6 shows that a mixed $\mathrm{Zr}-\mathrm{Te}$ compound is stable at potentials lower than $-3.1 \mathrm{~V}$ versus $\mathrm{F}^{-} / \mathrm{F}_{2}$ (gas). In another test, Alloy $\mathrm{C} 22$ was polarized at $-3.4 \mathrm{~V}$ versus $\mathrm{F}^{-} / \mathrm{F}_{2}$ (gas), potential lower than the critical potential for the formation of the $\mathrm{Zr}$ telluride compound. The specimen was kept immersed under polarization for 2 weeks at $953 \mathrm{~K}$ in $\mathrm{LiF}-\mathrm{CaF}_{2}-\mathrm{MgF}_{2}-\mathrm{ZrF}_{4}$ with tellurium vapor.

Fig. $5 \mathrm{c}$ shows a cross-section through this polarized specimen. Fig. $5 a$ and $c$ is visibly similar with a significant electrochemical corrosion but no evidence of intergranular attack, typical of the effect of tellurium vapor. At the applied polarization potential, $\mathrm{Cr}^{\mathrm{II}}$ and $\mathrm{Cr}^{\mathrm{III}}$ are expected to be formed; metallic chromium would only be stable at a potential lower than about $-3.8 \mathrm{~V}$. Therefore chromium oxidation should occur, in good agreement with the ob-

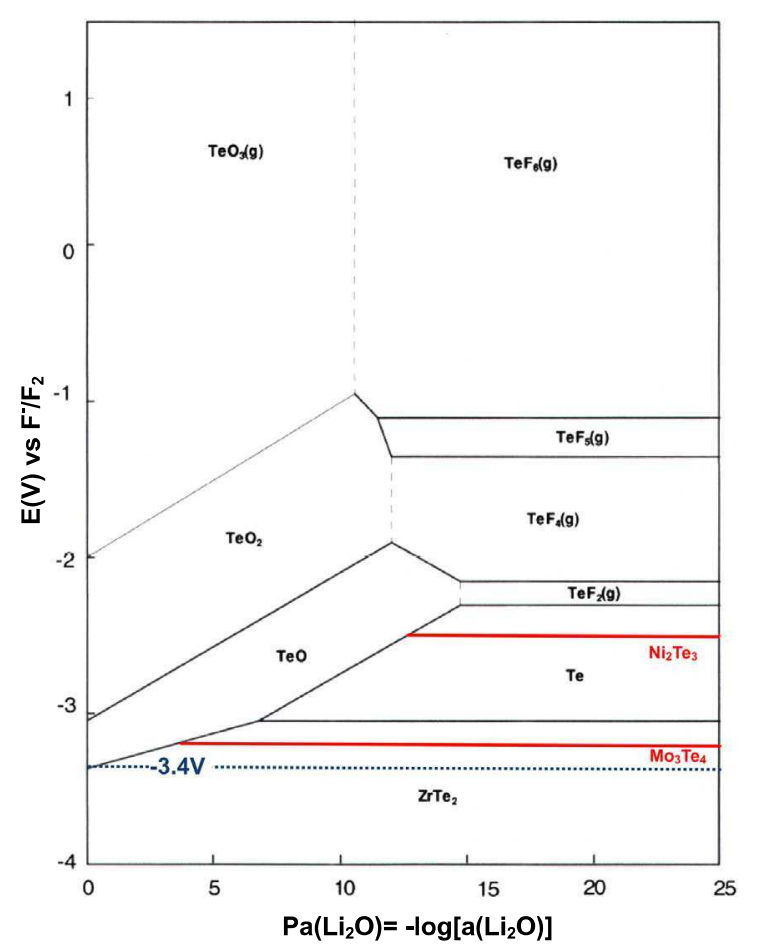

Fig. 6. Phase diagram at $953 \mathrm{~K}$ in the system $\mathrm{Zr}-\mathrm{Te}-\mathrm{F}-\mathrm{O}$ with lines from the diagrams for Ni-Te-F-O and Mo-Te-F-O [15]. served morphology. It is believed that tellurium formed a $\mathrm{ZrTe}_{2}$ compound with zirconium from the salt mixture.

This example shows that understanding of the salt electrochemical properties may help in tailoring polarization-based method to change the speciation of Te from a deleterious element at zero oxidation state to a non-corrosive compound. In practice, the use of a polarization is virtually impossible in a MSR system but control of the melt redox may be an option as was shown by ORNL [23] thru addition of the reducing element Be.

\section{Dissolution rate of metals in model fluoride melts}

Fig. 7 is a semilog plot of the curve anodic part in Fig. 1c. This classic representation helps in analyzing the corrosion properties. The tested metals exhibit two specific behaviors:

For $\mathrm{Cr}$ and $\mathrm{Fe}$, the anodic current continuously increases with increasing potentials following a straight line for overpotential higher than approx. $50 \mathrm{mV}$; this classic "Tafel evolution" implies that these two metals are directly dissolved in the test conditions, the reaction rate being controlled by activation at the metal/salt interface (and not by diffusion of corrosion products at the electrode).

For Ni, Mo and W, the anodic curves show two domains: a first area of low current densities then a linear increase occurring at overpotential above respectively $0.25 \mathrm{~V}, 0.6 \mathrm{~V}$ and $0.9 \mathrm{~V}$. Two hypotheses relating to the change in slope were initially proposed: either oxidation of $\mathrm{Ni}, \mathrm{Mo}$ and $\mathrm{W}$ takes place in two stages, or two different processes successively occur: the first process appears to proceed at a constant rate for all three metals; therefore, it is thought to involve a reaction independent of the electrode material, the second process is consistent with metal direct dissolution. This second case would imply that $\mathrm{Ni}$, Mo and $\mathrm{W}$ are stable in test conditions and would only be dissolved if polarized at more anodic potentials (more electropositive overpotentials). To check this later assumption, small amounts of $\mathrm{CrF}_{3}(3 \mathrm{~g}), \mathrm{FeF}_{2}(2 \mathrm{~g}), \mathrm{NiF}_{2}(3 \mathrm{~g})$ and $\mathrm{AgF}(0.5 \mathrm{~g})$ were added into different batches of LiF-NaF at $1173 \mathrm{~K}$. Voltammetry on a silver electrode confirmed that $\mathrm{CrF}_{3}$ and $\mathrm{FeF}_{2}$ were dissolved into the melt. Direct observation showed that $\mathrm{NiF}_{2}$ was spontaneously reduced with formation of metallic nickel floating onto the bath; $\mathrm{AgF}$ was shown to be reduced into silver that deposited at the crucible bottom.

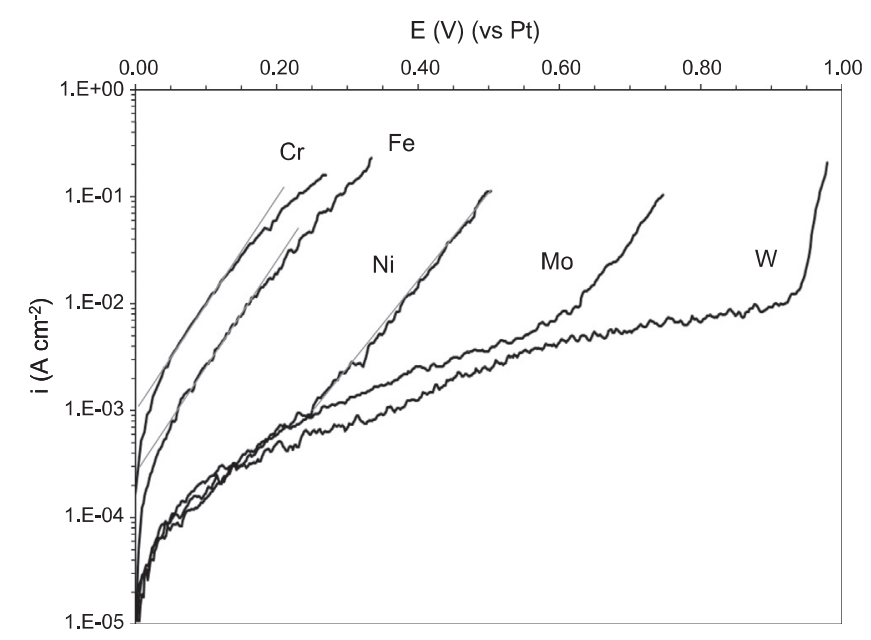

Fig. 7. Semilog plot of the anodic linear voltammograms from Fig. 1c. 
Based on the previous observations in $\mathrm{LiF}-\mathrm{NaF}$ at $1173 \mathrm{~K}$, it is believed that $\mathrm{Cr}$ and $\mathrm{Fe}$ are in an oxidized state while the stable form for $\mathrm{Ni}, \mathrm{Mo}, \mathrm{W}, \mathrm{Ag}, \mathrm{Pt}$ and $\mathrm{Au}$ is the metal. It was therefore assumed that the equilibrium potential of LiF-NaF lies between $E_{\text {ox }}(\mathrm{Fe})$ and $E_{\text {ox }}(\mathrm{Ni})$ e.i. $0.4 \mathrm{~V}<E_{\text {ocp }}<0.46 \mathrm{~V}$ using the potential series from Table 2. With the Pt pseudo-reference, it has not been possible to get more a precise value of the equilibrium potential, nor to elucidate which redox couple sets the potential.

Dissolution rates were evaluated for $\mathrm{Cr}$ and $\mathrm{Fe}$ in $\mathrm{LiF}-\mathrm{NaF}$ at the corrosion potential from measurement of the polarization resistance $R_{\mathrm{p}}\left(\Omega \mathrm{cm}^{2}\right)$. Potential was scanned from $-40 \mathrm{mV}$ to $+40 \mathrm{mV}$ around the corrosion potential at a scan rate of $1 \mathrm{mV} \mathrm{s}^{-1}$. The corrosion current density $i_{\text {corr }}\left(\mathrm{A} \mathrm{cm}^{-2}\right)$ verifies:

$i_{\text {corr }}=\frac{1}{R_{\mathrm{p}}} \frac{\beta_{\mathrm{ox}} \cdot \beta_{\mathrm{red}}}{2.3\left(\beta_{\mathrm{ox}}+\beta_{\mathrm{red}}\right)}$

and the corrosion rate $r_{\text {corr }}\left(\mathrm{mm} \mathrm{year}^{-1}\right)$ follows:

$r_{\text {corr }}=3.1510^{11} \frac{i_{\text {corr }} \cdot M_{\mathrm{M}}}{\mu_{\mathrm{M}} \cdot n \cdot \mathrm{F}}$

in which $M_{\mathrm{M}}$ is the metal molar mass $\left(\mathrm{g} \mathrm{mol}^{-1}\right), \mu_{\mathrm{M}}$ is the metal density $\left(\mathrm{kg} \mathrm{m}^{-3}\right), \beta_{\mathrm{ox}}$ and $\beta_{\text {red }}$ are the Tafel coefficients defined by $\beta_{\mathrm{ox}}=R T / \alpha_{\mathrm{ox}} n \mathrm{~F}$ and $\beta_{\text {red }}=R T / \alpha_{\mathrm{red}} n \mathrm{~F}, \alpha_{\mathrm{ox}}$ and $\alpha_{\text {red }}$ being the anodic and cathodic charge transfer coefficients considered to be equal to 0.5 ; the number of electrons exchanged is assumed to be two for $\mathrm{Cr}$ and $\mathrm{Fe}$.

Repeatability studies showed that the standard deviation on $i_{\text {corr }}$ is of about $40 \%$. Table 5 gives examples of $i_{\text {corr }}$ and $r_{\text {corr }}$ in LiF-NaF. The corrosion rate is one order of magnitude higher for $\mathrm{Cr}$ than for Fe. The activation energy for iron dissolution in LiF$\mathrm{NaF}$ was evaluated to be $127 \pm 47 \mathrm{~kJ} \mathrm{~mol}^{-1}$ in the temperature range $1073-1373 \mathrm{~K}$. The activation energy associated with diffusion of iron species was found to be about $50 \mathrm{~kJ} \mathrm{~mol}^{-1}$ in LiF$\mathrm{NaF}-\mathrm{KF}$ between 743 and $818 \mathrm{~K}$ [24]. Therefore it is believed that charge transfer might be rate limiting in agreement with the shape of the Fe curve in Fig. 7.

A Log/Log plot of the curves in Fig. 4 showed that $\mathrm{Ni}_{1-x} \mathrm{Cr}_{x}$ alloys with $x>0.22$, NiCrW (27 at.\%Cr) and Alloy C276 (21 at.\%Cr) are oxidized and dissolved in LiF-NaF at $1073 \mathrm{~K}$. Corrosion current densities were successfully evaluated from polarization resistances. Post-test SEM examinations and EDS analyses established that electrode surface was depleted in $\mathrm{Cr}$ and porosities were formed in laboratory alloys. These observations are consistent with the selective oxidation of chromium (oxidation of Fe may also occur in the Fe-containing Alloy C276).

Note that in all cases the metallic material directly dissolves into the molten salt, either spontaneously when immersed, or under anodic overpotential but no passivity was ever observed even for Cr-rich alloys (see Figs. 1, 2, 4 and 7). It is believed that any solid film made of oxide or even of fluoride might be soluble into the melt. Consistently no adherent product was ever observed by SEM on the specimen surface.

Table 5

Corrosion current density (standard error $40 \%$ ) and calculated corrosion rate for $\mathrm{Fe}, \mathrm{Cr}$ and $\mathrm{NiCr}$ electrodes in $\mathrm{LiF}-\mathrm{NaF}$.

\begin{tabular}{llrl}
\hline Material & Temperature $(\mathrm{K})$ & $i_{\text {corr }}\left(\mathrm{A} \mathrm{cm}^{2}\right)$ & $r_{\text {corr }}\left(\mathrm{mm} \mathrm{year}^{-1}\right)$ \\
\hline $\mathrm{Fe}$ & 1073 & $9.6 \times 10^{-5}$ & \\
$\mathrm{Fe}$ & 1173 & $8.4 \times 10^{-5}$ & 0.7 \\
$\mathrm{Fe}$ & 1273 & $1.6 \times 10^{-4}$ & \\
$\mathrm{Fe}$ & 1373 & $4.7 \times 10^{-4}$ & \\
$\mathrm{Cr}$ & 1173 & $7.2 \times 10^{-4}$ & 8.5 \\
$\mathrm{Ni}-53 \mathrm{Cr}$ & 1173 & $8 \times 10^{-4}$ & \\
$\mathrm{Ni}-33 \mathrm{Cr}$ & 1173 & $5 \times 10^{-4}$ & \\
$\mathrm{Ni}-22 \mathrm{Cr}$ & 1173 & $2.2 \times 10^{-4}$ & \\
\hline
\end{tabular}

Comparison of apparent oxidation potentials in Table 4 and corrosion current densities in Table 5 shows that the more electronegative $E_{\mathrm{ox}}(\mathrm{M})$, the higher the corrosion rate in a given media as commonly observed. Lower $E_{\mathrm{ox}}(\mathrm{M})$ actually induces more electronegative mixed potential with an higher corrosion current density. Diffusion processes into the alloy and in the molten salt may change this trend over exposure time.

\section{Conclusion}

Since the electrochemical reactions are rapid in fluorides at high temperature and passivity is practically impossible, thermochemical analysis should give an accurate description of metal/salt interactions. However, exact thermochemical calculations are virtually not achievable due to the system complexity where a salt mixture (two compounds or more) is in contact with a multi-element alloy. Besides, consistent thermodynamic data related to the liquid salt phase and the corrosion products are not available. Electrochemical techniques are an efficient tool to study reactivity of metals in molten salts and to assess kinetics. They were applied to investigate corrosion processes in molten fluorides using electrochemical cells made of inert materials: graphite, glassy carbon, BN, etc., under an inert atmosphere. Most of the experiments were performed using a platinum pseudo-reference electrode.

Linear voltammetry established that metal stability follows: $\mathrm{Cr}<\mathrm{Fe}<\mathrm{Ni}$, $\mathrm{Mo}<\mathrm{W}<\mathrm{Ag}<\mathrm{Au}$ in $\mathrm{LiF}-\mathrm{NaF}$ at $1173 \mathrm{~K}$, in good agreement with thermochemical calculations (assuming the oxidation state to be $n=2$ for $\mathrm{Cr}$, Fe and $\mathrm{Ni}, n=3$ for Mo and $\mathrm{Au}, n=6$ for $\mathrm{W}, n=1$ for $\mathrm{Ag}$ ). It showed that alloy elements have different corrosion behavior:

- $\mathrm{Cr}$ and $\mathrm{Fe}$ were dissolved in the molten salt.

- Ni, Mo, W, Ag, Pt and Au were stable.

Dissolution rates of $\mathrm{Cr}$ and $\mathrm{Fe}$ were assessed through measurement of the polarization resistance $R_{\mathrm{p}}$.

Testing of binary $\mathrm{Ni}-\mathrm{Cr}$ alloys showed that selective attack of $\mathrm{Cr}$ first occurred, and then at higher overpotentials both elements were oxidized. The corrosion rate was successfully calculated from $R_{\mathrm{p}}$. A thermochemical approach enabled accounting for the role of the alloy chromium content.

Complete analytical analysis of voltammograms for ternary and commercial alloys turned out to be complex. However, evaluation of the apparent oxidation potential and of the dissolution rate can be achieved, allowing a fast screening of alloys oxidation properties.

The presented results raised the question of the salt redox species involved in the oxidation-reduction process.

Finally, it was demonstrated that polarization may help in defining chemical conditions which could mitigate Te-induced embrittlement of sensitive materials by formation of a stable tellurium compound in the MSR salt.

The use of electrochemical techniques is envisioned as a fast and straight forward way to get some fundamental data on the salt/metal interaction at high temperature such as oxidation potentials, and dissolution rates. Therefore, it may be used to prepare, and then support analysis, of bigger, longer and more costly experiments like operation of convection loops.

\section{Acknowledgements}

This work received a financial support from the European Commission (ACSEPT Project) and from the French Research Project GEDEPEON/PACEN. 


\section{References}

[1] W.D. Manly, J.W. Allen, W.H. Cook, et al., Fluid Fuel Reactors (1958) 389.

[2] J.W. Koger, Corrosion 29 (1973) 115.

[3] J.R. DiStefano, J.H. De Van, J.R. Keiser, et al., Materials Considerations for Molten Salt Accelerator-based Plutonium Conversion Systems, ORNL/TM12925/R1, Oak Ridge National Laboratory, 1995.

[4] M. Noel, N. Suryanarayanan, J. Appl. Electrochem. 35 (1) (2005) 49.

[5] M. Straka, M. Korenko, F. Lisy, J. Radioanal. Nucl. Chem. 284 (1) (2010) 245

[6] L. Cassayre, P. Chamelot, L. Arurault, et al., Corros. Sci. 49 (9) (2007) 3610.

[7] B. Trémillon, Acid-base effects in molten electrolytes, in: Proc. NATO Advanced Institute on Molten Salt Chemistry: an introduction and selected applications, 1986.

[8] C.F. Baes Jr., The chemistry and thermodynamics of molten salt reactor fuels, in: Proc. AIME Nuclear Fuel Reprocessing Symposium, 1969.

[9] D. Olander, J. Nucl. Mater. 300 (2002) 270.

[10] H.W. Jenkins, G. Mamantov, D.L. Manning, J. Electrochem. Soc. 117 (1970) 183.

[11] K. Grjotheim, Z. Phys. Chem. 11 (1957) 150

[12] J.H. DeVan, Effect of Alloying Additions on Corrosion Behavior of NickelMolybdenum Alloys in Fused Fluoride Mixtures, ORNL-TM-2021, vol. 1, 1969.
[13] D.F. Williams, L.M. Toth, K.T. Clarno, Assessment of Candidate Molten Salt Coolants for the Advanced High-Temperature Reactor (AHTR), ORNL/TM-2006/ 12, Oak Ridge National Laboratory, 2006.

[14] S. Fabre, C. Cabet, L. Cassayre, et al., Mater. Sci. Forum 595-598 (2008) 483.

[15] HSC Chemistry v5.1, Outokumpu Research Oy, Pori, 2002.

[16] K. Wagner, S.R. Brankovic, N. Dimitrov, K. Sieradzki, J. Electrochem. Soc. 144 (1997) 3545.

[17] T. Tsuru, Mater. Sci. Eng. A 146 (1991) 1.

[18] H. Okamoto, in: Mary Anne Fleming (Ed.), Desk Handbook: Phase Diagrams for Binary Alloys, ASM International, Materials Park, OH, 2000, p. 273.

[19] FactSage Database - FACT Database for Hall Aluminium Process and FACT Salt Database, 2001.

[20] A.J. Bard, L.R. Faulkner, Electrochemical Methods - Fundamentals and Applications, second ed., John Wiley and sons, Tnc., New York, 2001.

[21] C.E. Campbell, W.J. Boetitinger, U.R. Kattner, Acta Mater. 50 (4) (2002) 775.

[22] W.R. Grimes, Nucl. Appl. Technol. 8 (2) (1970) 137.

[23] J.R. Keiser, Status of Tellurium-Hastelloy N Studies in Molten Fluoride Salts, ORNL/TM-6002, Oak Ridge National Laboratory, 1977.

[24] D.L. Manning, J. Electroanal. Chem. 6 (1963) 227. 